\title{
The 15-minute family interview: a family health strategy tool*
}

\author{
ENTREVISTA DE 15 MINUTOS: UMA FERRAMENTA DE ABORDAGEM À FAMÍLIA NA \\ ESTRATÉGIA SAÚDE DA FAMÍLIA \\ ENTREVISTA DE 15 MINUTOS: UNA HERRAMIENTA DE ABORDAJE FAMILIAR EN LA \\ ESTRATEGIA SALUD DE LA FAMILIA
}

\author{
Mariana Cristina Lobato dos Santos Ribeiro Silva ${ }^{1}$, Nancy \\ Jean Moules ${ }^{2}$, Lucía Silva ${ }^{3}$, Regina Szylit Bousso ${ }^{4}$
}

\begin{abstract}
The 15-minute family interview is a condensed form of the Calgary Family Assessment and Intervention Models (CFAM and CFIM) that aims to contribute to the establishment of a therapeutic relationship between nurses and family and to implement interventions to promote health and suffering relief, even during brief interactions. This study investigated the experience of nurses from the Family Health Strategy (FHS) who used the 15-minute interview on postpartum home. The qualitative research was conducted in three stages: participants' training program, utilization of the 15-minute family interview by participants, and interviews with nurses. The data were collected through semistructured interviews with eight nurses. The thematic analysis revealed two main themes: dealing with the challenge of a new practice and evaluating the assignment. This work shows that this tool can be used to deepen relationships between nurses and families in the Family Health Strategy.
\end{abstract}

\section{DESCRITORES}

Family nursing

Family health

Professional-family relations

\begin{abstract}
RESUMO
A entrevista de 15 minutos trata-se de uma forma condensada do Modelo Calgary de Avaliação e Intervenção com famílias, visando contribuir para o estabelecimento de relacionamento entre enfermeiro e família, de modo que, mesmo em breve interação, possibilite intervenções que promovam saúde e alívio do sofrimento. Esse estudo objetivou conhecer a experiência de enfermeiros da Estratégia Saúde da Família (ESF) no uso da Entrevista de 15 minutos nas visitas domiciliárias realizadas no período puerperal. A pesquisa qualitativa ocorreu em três etapas: treinamento dos participantes, utilização da entrevista de 15 minutos pelos enfermeiros e entrevistas com os enfermeiros. Os dados foram coletados por meio de entrevistas semi-estruturadas com oito enfermeiros. A análise temática evidenciou dois temas centrais: vivendo o desafio de uma nova experiência e avaliando a experiência. $\mathrm{O}$ trabalho evidencia que essa ferramenta pode atuar como um contexto que facilita o aprofundamento das relações entre enfermeiros e famílias na Estratégia Saúde da Família.
\end{abstract}

\author{
DESCRIPTORS \\ Enfermagem familiar \\ Saúde da família \\ Relações profissional-família
}

\begin{abstract}
RESUMEN
La entrevista de 15 minutos es una abreviación del Modelo Calgary de Evaluación e Intervención con familias, apuntando a establecer relación entre enfermero y familia, para que, en breve interacción, posibilite intervenciones promotoras de salud y alivio del sufrimiento. Se objetivó conocer la experiencia de enfermeros de la Estrategia Salud de la Familia (ESF) en la utilización de la Entrevista de 15 minutos en visitas domiciliarias realizadas en el período puerperal. La investigación cualitativa sucedió en tres etapas: entrenamiento de los participantes, utilización de la entrevista de 15 minutos por los enfermeros y entrevistas con los enfermeros. Datos recolectados mediante entrevistas semiestructuradas con ocho enfermeros. El análisis temático evidenció dos temas centrales: viviendo el desafio de una nueva experiencia y evaluando la experiencia. El trabajo demuestra que la herramienta actúa como un contexto facilitador de la profundización de relaciones entre enfermeros y familias en la Estrategia Salud de la Familia.
\end{abstract}

\section{DESCRIPTORES}

Enfermería de la familia

Salud de la familia

Relaciones profesional-familia

\footnotetext{
*Extracted from the thesis "Entrevista de 15 minutos: uma ferramenta de abordagem à família no Programa Saúde da Família", University of São Paulo, School of Nursing, 2010. ${ }^{1}$ RN. M. Sc. in Nursing. School of Nursing, University of São Paulo. Sao Paulo, SP, Brazil. marianalobatorb@terra.com.br ${ }^{2}$ Associate Professor of Faculty of Nursing, University of Calgary. Calgary, Alberta, Canada. njmoules@ucalgary.ca. ${ }^{3}$ Ph. D. in Sciences. School of Nursing, University of Sao Paulo. Researcher of the Interdisciplinary Research Group on Loss and Grief (NIPPEL/USP). Professor of Nove de Julho University. São Paulo, SP, Brazil. luciasilva@usp.br ${ }^{4}$ Associate Professor in Department of Maternal-Infant and Psychiatric Nursing School of Nursing, University of Sao Paulo. Leader and Researcher of the Interdisciplinary Research Group on Loss and Grief (NIPPEL/USP). Member of the Association for Death Education and Counseling (ADEC). São Paulo, SP, Brazil. szylit@usp.br
}

$\begin{aligned} \text { Rev Esc Enferm USP } & \text { Recebido: } 07 / 11 / 2011 \\ \text { 2013; } 47(3): 634-9 & \text { Aprovado: } 16 / 10 / 2012\end{aligned}$




\section{IINTRODUCTION}

The Family Health Program (FHP) was implemented in Brazil in 1994 in an attempt to reorganize the National Health System, especially primary health care. In the process of prioritizing actions to protect and promote health, each Family Health Team discovers the reality of families that they are responsible for as they register and identify their characteristics and become more sensitive to their needs ${ }^{(1)}$.

The FHP has several innovative characteristics, including an emphasis on reorganizing primary care as the gatekeeper of the health system; integrating primary care with other social and health services; changing the focus of care from the individual to the family and community; and developing community participation and outreach methods, such as regular visits to each household in a given geographic district.

Home visits to families are carried out systematically. As an example, home visits happen between the third and seventh days after delivery, with the aim to meet the families when they face major shifts in adapting to a new infant ${ }^{(2)}$.

Stating that the family is the central focus of primary care, however, does not guarantee that it will occur in Brazil's FHP(3). While the FHP has a strong system of guidelines regarding professional practice conduct, it neglects to address the issues created by family dynamics ${ }^{(4)}$. In their daily practice, health workers might try to develop a focus toward families, but it still happens informally and is not systematic.

The use of assessment models and interventions has proven to be an effective strategy for establishing therapeutic relationships between health professionals and families. This approach enables needs to be identified and actions to be implemented that will address the requirements of each family ${ }^{(5)}$ and can also facilitate the enhancement of family-nurse interactions ${ }^{(6)}$.

The Nurses and Families: A Guide to Family Assessment and Intervention ${ }^{(7)}$ presents the Calgary Family Assessment Model (CFAM) and the Calgary Family Intervention Model (CFIM). These models propose a multidimensional framework for family evaluation and an organized structure of family intervention that helps to promote change and health. Specifically, the models highlight the family-nurse relationship by focusing on the intersection between the function of family members and the interventions performed by nurses.

In Brazil, the CFAM and the CFIM have been mentioned in the literature through reports of experiences in the $\mathrm{FHP}^{(8-9)}$, and the researchers considered the CFAM to be very helpful in the organization of the great amount of information obtained through the family interview and assessment ${ }^{(10)}$.

The 15-minute family interview is a condensed version of the CFAM and CFIM and includes its essential elements. The key components that comprise the 15-minute family interview are: manners, therapeutic conversation, family genogram (and in some situations an ecomap), therapeutic questions, and commendations ${ }^{(7)}$. The 15-Minute Family Interview can be adapted for various scenarios by different nurses ${ }^{(11-13)}$. The aim of the study was to investigate the Brazil's Primary Care - FHP nurses' experience of using the 15-minute family interview within home visits during the early postpartum period.

\section{METHOD}

\section{Design}

The qualitative study took place in three Basic Health Units (BHU) in Sao Paulo, Brazil. Each BHU has from four to six Family Health Teams that each include a doctor, a nurse, two nursing assistants, and community health agents who live in the community and are based in a geographically defined coverage area.

All nurses from these BHUs who agreed to take part in a training program about the use of the 15-minute family interview were invited to participate in the study after approval by the Research Ethics Committee of School of Nursing of University of Sao Paulo, process number $773 / 2008$. The study was also approved by the Research Ethics Committee of the Municipal Health Secretary of the City of Sao Paulo, process number 0162.0.162.000-8.

\section{Procedures}

The investigation was divided into three stages.

Stage 1 - Training program for participating registered nurses

The training was provided free of charge by a family nursing specialist and the researcher over 8 hours divided into 2 separate days, with 2 groups of registered nurses. A total of 12 registered nurses participated in the training program. All registered nurses had more than 2 years of practice in the FHP, and 11 of then had specialization degrees in Primary Health Care. Although 12 nurses participated in the training stage, only 8 completed the study. The other four nurses who participated in the training did not perform home visits using the 15-minute family interview within the time that was established for data collection.

The training was comprised of an overview of the CFAM and $\mathrm{CFIM}^{(7)}$, including a general introduction to the genogram 
and ecomap, stages of family development, tasks and bonds, beliefs and values, general principles of family systems theory, and circular patterns of interaction theory. The purpose of this discussion was to contextualize the 15-minute family interview so that participants could have a better understanding about the model that led to its development. The registered nurses' beliefs concerning family and how to approach it in their practice were also discussed, as well as their personal and professional experiences. The 15-minute family interview was discussed in detail as a family assessment and intervention tool. The nurses were received a printed version as support material for the application of the 15-minute family interview, which was adapted from the book Nurses and Families: $A$ Guide to Family Assessment and Intervention ${ }^{(7)}$.

\section{Stage 2 - Utilization of the 15-minute family interview by participating nurses}

After the training program, registered nurses were instructed to employ the 15-minute family interview during postpartum home visits. FHP nurses usually make family home visits during this period as prescribed in the Women and Children's Health Nursing Protocol of the FHP. They also carry out prenatal and childcare consultations, administer vaccines, provide orientation sessions, and facilitate therapeutic group activities.

\section{Stage 3 - Individual interviews with participating nurses}

Eight registered nurses took part in this last stage of the research. Unstructured interviews were conducted in the nurses' workplace after they had completed two mock interviews during home visits. This interview was carried out in an attempt to understand the nurses' experience using the 15-minute family interview. All participants signed a consent form.

\section{Data analysis}

Thematic analysis was used for the identification, analysis, and registration of patterns (themes), based on the data collected ${ }^{(14)}$. A theme must capture something important from the data that represents a pattern and is related to the research question and answer it at some level. However, themes are not simply items found in the obtained material; rather, they are identified through the researcher's interpretation of the material(14).

\section{RESULTS}

The detailed analysis of the interviews with the participating nurses led to the identification of two main themes: dealing with the challenge of a new practice and evaluating the challenge. These different aspects of the nurses' experiences are presented below: the main themes are in bold, are the categories that were identified through them are underlined.

Dealing with the challenge of a new practice refers to the moment in which nurses have their first experience with the 15-minute family interview and begin to use it home visits. After taking part in the training program, nurses begin to make use of the key components and succeed or find difficulty in the different situations. This theme is composed of five categories that reflect the experience of this challenge.

The first category, Taking the chance of a new experience describes the stage at which the nurses, having decided to take part in this study, complete the training program at Stage 1 of this research. In Creating strategies to accomplish the 15-minute family interview, nurses start developing different approaches to face the difficulties they experience when using some of the key components of the interview in home visits. As one nurse reported:

It was a puerperal home visit, and I started straight by showing the genogram. I explained it to the person, you know... I started by that, by telling that it was for me to get to know the family and all (Nurse 5).

As nurses begin using the interview, they experience Being surprised while completing the therapeutic questions because they realize that administering the interview provides opportunity for the families to share their needs. One nurse said

She opened herself so much that I could notice she had more doubts, and she asked me things that I would have never imagined she would ask... (Nurse 1).

With regard to Feeling pleased to offer commendations, nurses experienced joy and satisfaction when using this key part of the 15-minute family interview. Another nurse mentioned that:

She smiled... She was a little tense when I started, but she got happy afterwards. I realized by the non-verbal acts of hers that it was very favorable - she needed to hear that to feel stronger and more confident. (Nurse 2).

Thus, from the therapeutic questions and the commendations, nurses begin Recognizing space for therapeutic conversation. These interactions can occur throughout the experiences between nurses and families, but when using the key components of the interview, professionals note that they are providing an opportunity for listening and for exchanging, which means that, besides offering information, they also listen to the family's needs and their reports of their experiences of health and illness. One of the nurses shared that

When I asked her the therapeutic question I could see that she was feeling watched and looked after (Nurse 2).

The second theme identified is evaluating the challenge. In this stage, nurses analyze the results of the use of the 15-minute family interview on puerperal home visits. It is also a self-assessment stage, as nurses evaluate the results of the interview appliance on their own personal and professional aspects. Eight categories make up this theme, expressing the different perceptions of nurses on the results of these experiences. 
Reconsidering family practice happens when nurses, after having used the 15-minute family interview, refer back to their previous experiences (before using the interview) and consider the difficulties they encountered making a family assessment and intervention model during their practice. As one of the professional said:

...we were too much focused on the baby and not so much on the family... We do know the family and we worry about them, but because we don't do it (the 15-minute Family Interview); we carry on by worrying mostly about the baby... (Nurse 7).

Although they already understood the impact of this new tool in their practice, nurses still reported Feeling insecure about the challenge of introducing an innovative procedure into their established routines. As one of the nurses said:

In the beginning, I mean, in the first and second times, I started being in doubt... I had never used the 15 minute family interview - or any of its key ingredients - before, I have worked for 10 years in FHP and I hadn't... (Nurse 1).

One issue that caused concern was the time spent for exercising this new practice. Despite the term 15-minute family interview, professionals fear that the introduction of new elements into their job routines will overload them with tasks. In this sense, nurses' understanding is of Time not being a hindrance, as they perceive the time used to accomplish the interview as time well spent.

One nurse described this situation:

So forme, the interview is feasible, although it took more than 15 minutes. In addition, you'll only do this interview once, for that reason, even if it takes long time, I can spare more time for that specific consultation (Nurse 5).

Thus, nurses recognize the experience as Being rewarding, declaring that the interview is a beneficial and pleasant experience, especially as they notice the positive results of their work on family assessment and intervention. A nurse even mentioned that:

I thought it was so beautiful! When I asked: 'How can we be more helpful to you and to your family during this assistance?', she answered: 'Just by coming here'. She was feeling looked after. I felt so good. (Nurse 2).

Moreover, when a family's engagement does not occur in an appropriate way, nurses' perceptions change. As a consequence, Feeling uncomfortable means the nurses' perception of the 15-minute family interview changes when it becomes a burden or something that appears to be imposed on the family. One of the nurses reported an example:

At first, I thought it was interesting, but I..., actually, it wasn't, because the mother had a breastfeeding problem and I seemed to be imposing that (the 15-minute family interview) as an obligation to her... For these reasons, the interview seemed a little forced, it wasn't nice...(Nurse 2).
Having to be accomplished in an appropriate moment describes the nurses' conclusions about their experiences with the 15-minute family interview. The professionals realized that the key to accomplishing the interview was achieving the moment in which the nurse and the family felt comfortable enough to share their experiences and acknowledgements, providing space to gather information for family assessment and enhance therapeutic communication. As one nurse said:

I think the two families that I interview appreciated it because if I had stayed there, they would have kept talking! They were very needy! (Nurse 3).

After having faced the challenge of introducing a new element into their job routine and being exposed to a new family procedure, nurses realized the benefits obtained, Being surprised by the benefits of the challenge. One of the nurses reported:

But after I did the first one, I enjoyed it a lot, because I could see things that I would never have seen in other way. The first time I did that I found out that the mother doesn't know who the father of her child is and I would never have discovered that otherwise... (Nurse 5).

Moreover, nurses noted that the 15-minute family interview is a means of Going beyond the protocol. That is, nurses determined that the use of the 15-minute family interview did not keep them from executing the prescribed - and necessary - tasks of the Women and Children's Health Nursing Protocol of the FHP. On the contrary, it is a tool that enables nurses to go further and to make good use of an opportunity, once the moment is appropriate, of understanding a family's experience of the birth of a new member. As an example, one nurse mentioned that:

By not using that (the 15-minute family interview) many times we end up seeing the breastfeeding problems and not the family (Nurse 2).

Therefore, professionals begin to look beyond biomedical matters (hygiene, breastfeeding, pain...), beyond the mother-child relationship, and into the whole family system and its wider social support networks.

\section{DISCUSSION}

The analysis of the interviews allowed us to understand that the professionals considered this assignment a challenge because it introduced a new practice into their established routines.

Despite perceiving that they are better prepared for family practice after the training, nurses still expressed doubts about the usefulness of the 15-minute family interview. Thus, they feel uneasy using the key components, and experienced different levels of difficulty and success. When using this new tool, however, the health professionals expressed surprise at the broad range of information they learned when using the 15-minute family interview in their work. 
These results are very similar to those obtained in other studies that also used the CFAM, the CFIM, and the 15-minute family interview in nurse training. These studies were conducted in different scenarios, including a pediatric hospital(12), a psychiatric hospital(15) and a pediatric rehabilitation hospital (6). The similarity of those results with the findings of our study reveals that the 15-minute family interview is a very flexible tool that is adaptable to different scenarios ${ }^{(11)}$

It is important to stress that, for FHP nurses, the relationship that is developed between them and the family they assist through the use of the 15-minute family interview is in itself a fundamental gain, since, by the definition of the Brazilian Health Ministry itself, the FHP serves as a central point to establish ties between health professionals and the population they serve ${ }^{(1)}$. The relationship is considered a central issue in the practice of public health nurses who work with families ${ }^{(16)}$. In this respect, trust and support are some of the most important factors in the relationship between public health nurses and families in home visits ${ }^{(17)}$.

By using the 15-minute family interview, the professionals understand they are Recognizing space for therapeutic conversation. The communication that is established allows the family to express their concerns and strengths, helping nurses to move forward toward a practice in which the family is the object of assistance. At the same time, while trying to meet the challenge of using the 15-minute family interview during home visits, nurses also face some difficulties, which can lead professionals to experience anxiety and uneasiness.

The literature described some of the difficulties faced by health professionals while employing this new approach with families, including commendations and problems in engaging with families and different levels of uneasiness in the use of genograms ${ }^{(12)}$. In order to make the genogram and ecomap time-efficient, it is necessary to focus on family member data such as age, occupation, religion, and health status ${ }^{(7)}$.

In our study, we found that nurses also faced difficulties in engaging with families when they feel that the moment is not appropriate for carrying out the 15-minute family interview, for example, when the family expresses great distress or discomfort owing to a embarrassing issue, such as breastfeeding problems or family conflicts. In order to create an environment that is favorable to change, it is important to have a clear understanding of the main concerns of families and to recognize their suffering, expectations and anxieties ${ }^{(7)}$.

The families served by the FHP usually receive home visits from nurses during the first week after birth; however, the assessment of family relationships is not specified as an objective of this service. The establishment of the parent-infant relationship is one of the most important issues in early parenting, being a period of reorganization, conflict, and establishing new patterns of family relationships ${ }^{(2)}$.

Although nurses are increasingly aware of the need to include the family in health care, the difficulty in implementing practices with families still persists due to a lack of theoretical references and tools ${ }^{(18)}$.

An systematic literature review of research on the aspects that can contribute to overcoming obstacles associated with a family-focused approach model has been published recently ${ }^{(19)}$. It is becoming more apparent that every encounter between a nurse and a family, whether it lasts five minutes or five years, has the potential to create a context for learning and healing ${ }^{(7)}$. It is within this context that the Brazilian FHPnurses deal with an enormous variety of situations and tasks that might affect the health of the 1,000 families that each one of them are responsible for.

The proposal to employ the 15-minute family interview was initially considered very challenging. Nevertheless, we found that when nurses opened themselves to the experience of using the 15-minute family interview in their work with families in the puerperium, they noticed a significant impact on their relationship with them, aseach family could beaddressed in a unique way due to the flexibility and adaptability ofthe interview format.

\section{CONCLUSION}

This study provides important information regarding Brazilian Primary Health Care - FHP nurses' experiences of utilizing the 15-minute family interview during their family practice. The establishment of open and collaborative relationships among nurses and families is essential to Primary Health Care practice. From this study, we were able to observe how nurses could increase their knowledge about the families they treating by using the 15-minute family interview and also analyze how it provided a way to implement new interventions and strengthen the nurse-family relationship.

In thissense, it is importantthat the Brazilian Health Ministry begin tofocus on the family assessmentand appropriate interventionsduringthe introductory training for Family Health Program practitioners.

However, it is important to emphasize that the creation of a favorable context for the exchange of experiences, information, suffering, and strength among nurses and families depend on the adoption of theoretical references and instruments and the recognition that beliefs and values - from both nurses and families -can impede these interactions. Once those beliefs are recognized and the obstacles are removed, strong therapeutic relationships can be established between families and health care professionals. 
1. Brasil. Ministério da Saúde; Secretaria de Políticas de Saúde, Departamento de Atenção Básica. Programa Saúde da Família. Rev Saúde Pública. 2000;34(3):316-9.

2. Bell L, Goulet C, St-Cyr Tribble D, Paul D, Boisclair A, Tronick EZ. Mothers' and fathers' views of the interdependence of their relationships with their infant: a systems perspective on early family relationships. J Fam Nurs. 2007;13(2):179-200.

3. Oliveira RG, Marcon SS. The opinion of nurses regarding the work they perform with families in the Family Health Program. Rev Latino Am Enferm. 2007;15(3)431-8.

4. Ribeiro EM. Different approaches to the family in the context of the Family Health Program/Strategy. Rev Latino Am Enferm. 2004;12(4):658-64.

5. Leahey M, Svavarsdottir EK. Implementing family nursing: how do we translate knowledge into clinical practice? J Fam Nurs. 2009;15(4):445-60.

6. LeGrow K, Rossen BE. Development of professional practice based on a family systems nursing framework: nurses' and families' experiences. J Fam Nurs. 2005;11(1):38-58.

7. Wright LM, Leahey M. Nurses and families: a guide to family assessment and intervention. 5th ed. Philadelphia: F. A. Davi; 2009.

8. Silva L, Bousso RS, Galera SAF. The use of the Calgary Model for assessment of families of the aged in clinical practice. Rev Bras Enferm. 2009;62(4):530-4.

9. Moura LS, Kantorski LP, Galera SAF. Assessment and intervention in families attended by the family health team. Rev Gaúcha Enferm. 2006;27(1):35-44.

10. Mendes AMC, Bousso RS. The challenge of learning and caring for a family while in nursing school. REME Rev Min Enferm. 2006;10(1):79-81.
11. Holtslander L. Clinical application of the 15-minute family interview: addressing the needs of potstpartum families. J Fam Nurs. 2005;11(1):5-18.

12. Matinez AM, D'Artois D, Rennick JE. Does the 15-minute (or less) family interview influence Family Nursing Practice? J Fam Nurs. 2007;13(2):157-1.

13. Wright LM, Leahey M. Maximizing time, minimizing suffering: the 15-minute (or less) family interview. J Fam Nurs. 1999;5(3):259-74.

14. Braun V, Clarke V. Using thematic analysis in psychology. Qual Res Psychol. 2006;3(2)77-101.

15. Goudreau J, Duhamel F, Ricard N. The impact of a family systems nursing educational program on the practice of psychiatric nurses: a pilot study. J Fam Nurs. 2006;12(3):292-306.

16. Moules NJ, MacLeod MLP, Thirsk LM, Hanlon N. "And then you'll see her in the grocery store": the working relationships of public health nurses and high-priority families in Northern Canadian communities. J Pediatr Nurs. 2010;25(5):327-34.

17. Heaman M, Chalmers K, Woodgate R, Brown J. Relationship work in an early childhood home visiting program. J Pediatr Nurs. 2007;22(4):319-30.

18. Bousso RS. The family decision-making process concerning consent for donating their child's organs: a substantive theory. Texto Contexto Enferm. 2008;17(1):45-54.

19. Silva MCLSR, Silva L, Bousso RS. Approaching the family in the Family Health Strategy: an integrative literature review. Rev Esc Enferm USP [Internet]. 2011 [cited 2012 Jan 22];45(5):1250-5. Available from: http://www.scielo.br/pdf/ reeusp/v45n5/en_v45n5a31.pdf 